\title{
Injectable Suspension Dosage Form
}

National Cancer Institute

\section{Source}

National Cancer Institute. Injectable Suspension Dosage Form. NCI Thesaurus. Code C42995.

A suspension intended for injection. 